\title{
THE ARIES DIAMONDIFEROUS KIMBERLITE PIPE CENTRAL KIMBERLEY BLOCK, WESTERN AUSTRALIA.
}

\author{
Towie, ${ }^{(1)}$ N.J.; Marx, ${ }^{(2)}$ M.R.; Bush, ${ }^{(1)}$ M.D. and Manning, ${ }^{(2)}$ E.R.
}

(1) Triad Minerals N.L., Melbourne, Victoria, Australia; (2) Poseidon Exploration Ltd., Adelaide, SA, Australia.

The Aries kimberlite pipe is situated in the Kimberley Region of Western Australia, $270 \mathrm{~km}$ east-north-east of the coastal town of Derby and $250 \mathrm{~km}$ west of the Argyle diamond mine.

The pipe is intruded into the Proterozoic sediments and basalts comprising the Kimberley Basin which is thought to be underlain by an Archean cratonic basement.

The pipe has been dated by the $\mathrm{Rb}-\mathrm{Sr}$ phlogopite method at about $820 \mathrm{Ma}$ (C.B. Smith 1989) Nearby tillites provide evidence of subsequent glaciation at $700 \mathrm{ma}$.

\section{EXPLORATION}

Systematic diamond exploration of the Kimberley Region commenced in 1971 and this led to the discovery of numerous kimberlites and lamproites including the Argyle pipe in the period from 1975 to 1980 .

Traditional drainage sampling by the Triad/Freeport partners confirmed the presence of kimberlitic chrome spinels which led to the Aries pipe discovery in 1985.

Three depressions up to $20 \mathrm{~m}$ deep form the surface expression of the kimberlite within the sandstone country rock and are easily visible on aerial photographs.

The 40 Nanoteslar aeromagnetic response is distinctive but not dipolar.

The VLF magnetic and electric field signatures fairly consistently but not invariably define the pipe contact zones.

The surface spectral signature as detected by the Geoscan MKII multispectral scanner indicates a clear anomaly in band ratios typical of montmorillonite.

III. THE ARIES PIPE

\section{A. Structural}

The size of the pipe is 20 hectares based on contacts primarily inferred from sandstone outcrop. Limited drilling to a maximum depth of $100 \mathrm{~m}$ has shown that the wall rock contacts dip at $60-80^{\circ}$. There are four distinct lobes.

The northern extension appears to either contain massive reefs of basalt and sandstone. or else it has a small central core with radiating dykes and sills. 
A 1m thick sill has been confirmed approximately $100 \mathrm{~m}$ from the centre of this lobe.

The northern lobe is mostly xenolithic breccia with 95\% basalt xenoliths and $<5 \%$ kimberlite matrix.

The central lobe contains two large basalt reefs and in the vicinity of these the predominant rock type is xenolithic breccia as above. Kimberlite, micaceous kimberlite and kimberlite breccia with little xenolithic dilution are found in the southeast portion of the lobe.

The southern lobe is mostly kimberlite breccia with a high dolerite and sandstone content as well as basalt. It degenerates into a zone of brecciated quartzite country rock with kimberlite dykes in the southern tail.

The top $20 \mathrm{~m}$ of the kimberlite is heavily oxidized to clay with a sharp transition to silicified kimberlite separated by a thin laterite layer. In the central lobe there are $1-4 \mathrm{~m}$ of overlying ferruginous gravels with a marked depletion of $-2 \mathrm{~mm}$ diamonds compared to the underlying kimberlite. This indicates a fossil drainage no longer visible. Clayey silt overlies the gravel ranging from several centimetres to $6 \mathrm{~m}$ depth.

\section{B. Geochemistry}

A loam sample taken from the central lobe in the surficial clayey silt gave no anomalous geochemical signature compared to the nearby basaltic soils apart from enhancement of $\mathrm{Cr}$ and $\mathrm{Zr}(0.4 \%$ on Kimberlite). Compared to proximal doleritic soils $\mathrm{Cr}, \mathrm{Ni}$ and La have been shown to be énhanced. A kimberlite soil analysis is given in table 1.

The yellow ground analysis shows a surprising similarity to the soil sample from above. This sample of yellow ground was taken from weathered kimberlite breccia with $<20 \%$ Xenolithic dilution.

TABLE 1 (Values in ppm)

$\begin{array}{lrrrrrrrrr}\text { ELEMENT : } & \text { Nb } & \text { Nd } & \text { Ce } & \text { La } & \text { V } & \text { Cr } & \text { Ni } & \text { Sr } & \text { Ba } \\ \text { Surface Soil } & 11 & <20 & \text { NA } & 17 & 23 & 415 & 14 & 8 & 56 \\ \text { Yellow ground } & 10 & <2 & 70 & 20 & 100 & \text { NA } & <5 & 50 & 210 \\ \text { (6m depth) } & & & & & & & & \end{array}$

\section{ALLUVIALS}

The extensive alluvial deposits downstream of the Aries pipe were initially detected and outlined by the surface chromite distribution pattern within the Harris Creek valley system.

At least three gravel horizons west were uncovered, the ages of which are thought to date from Miocene to present times. The two main channel deposits are weakly diamondiferous. 